dr Iwona Kalenik

Akademia Sztuk Pięknych w Warszawie

Artykul artystyczno-badawezy

TOM 2 (2021), NR 1

\title{
SILA MIEJSKIEJPUSTKI
}
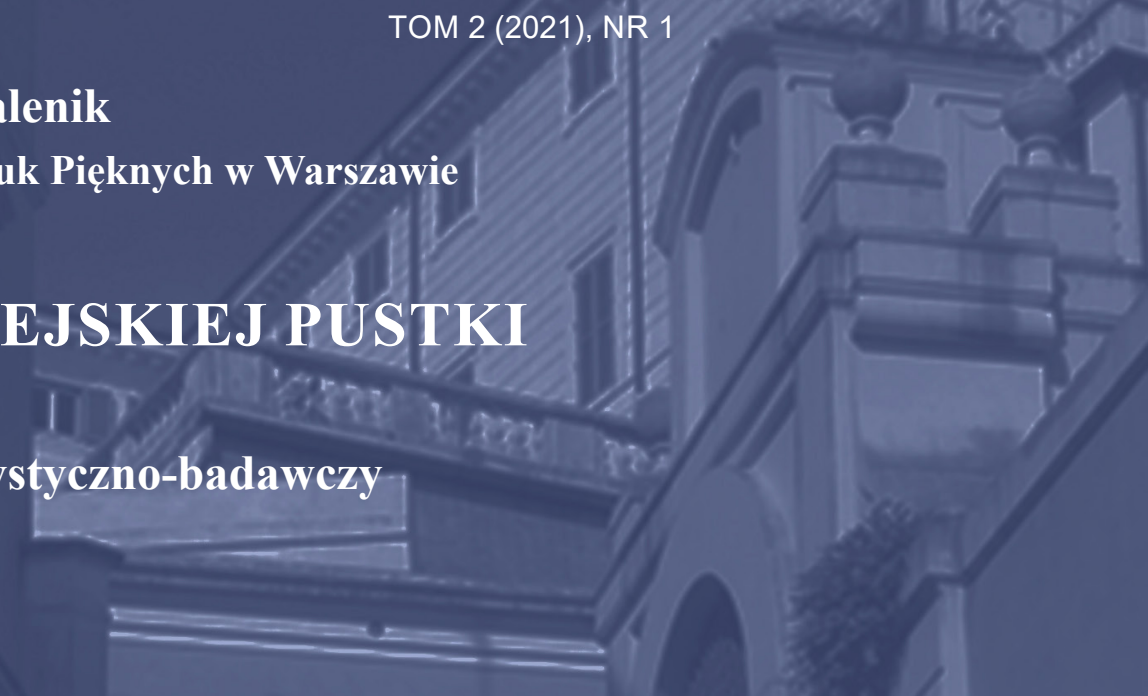

\section{Spis treści}

Abstrakt 165

Słowa klucze 165

Wstęp 166

Czucie 167

Bycie w 169

Zatrzymanie 171

Spotkanie 174

Dialog 176

Bibliografia 179

Źródła fotografii 180 
TOM 2 (2021), NR 1

\begin{abstract}
Abstrakt
„W czasie zarazy” życie miasta toczy się dalej, zmieniając swój rytm i dostosowując się do trudnych okoliczności i ograniczeń. Wycofuje się do strefy prywatnej, do wnętrz ukrytych za grubymi murami. Balkony, niczym łączniki między wnętrzem i zewnętrzem, stają się przestrzeniami o nieocenionej wartości. Tak jak rozedrgania fasad, schody, nisze, podcienie i arkady, rozwarstwienia w warstwie architektonicznej, które pozwalają uznać przestrzeń miasta za przyjazną, bo dającą się dotknąć, poczuć, pozwalają przysiąść i odpocząć, pobyć. Nawet wtedy, gdy nie oferuje atrakcji, nie migocze światłami kawiarni, nie zaprasza do galerii sztuki ani na wieczorne spektakle teatralne. Miasto dotknięte pandemią zamyka miejsca spotkań - restauracje, galerie sztuki, kina. Jednocześnie kryzys obnaża siłę miejskiej pustki - przestrzeni ulic, placów, formowanych fasadami budynków oraz odsłania potencjał otwartych miejsc spotkań, przestrzeni spacerów i miejskich włóczęg. Jeśli nie są inspirujące, nie poruszają, miasto cichnie i obumiera, mieszkańcy nie mają dokąd pójść, nie mogą spotkać się i poczuć „w mieście”. Są jednak takie, które nie oferując nic poza swoją formą, wciąż są odwiedzane, nie tracą życia, przyciągają mieszkańców. W czym tkwi sekret ich niezwykłej jakości? Jak warstwa architektoniczna przestrzeni publicznych wpływa na zachowania mieszkańców? Czy pozbawiona „eventów” i komercyjnych atrakcji przestrzeń może zachęcać do bycia w niej?

Artykuł podejmuje temat przestrzeni jako miejsca spotkań i zawiera analizę oraz interpretację obserwacji kilku wybranych przestrzeni miejskich pod kątem ich potencjału bycia przestrzeniami spotkań.
\end{abstract}

\title{
Słowa klucze
}

architektura miasta, przestrzeń publiczna, miejsce, doświadczanie przestrzeni architektonicznej, odczuwanie architektury 
TOM 2 (2021), NR 1

\section{Wstęp}

Kiedy na początku 2020 roku ogłoszono wybuch pandemii Sars-CoV-2 w Europie, musiałam odwołać swoje plany. Wiedziałam już, że nie pojadę do Rzymu, by po raz kolejny bez planu poszwendać się po mieście i że nie uda mi się „zniknąć” w gwarze rzymskiej przestrzeni, poczuć po raz kolejny, jak wspaniałe miejsca oferuje. Właśnie tam, we Włoszech, które to państwo jako pierwsze w Europie stanęło na linii frontu walki z nieznanym wirusem, sytuacja epidemiologiczna była najtrudniejsza. W całej Europie, w niemal każdym kraju, wprowadzano zakazy podróży, odwoływano loty i zamykano granice.

Odbyłam jednak wtedy szereg przechadzek po moim mieście - Warszawie. Chciałam zobaczyć, jak wygląda opustoszałe miasto, doświadczyć przestrzeni, której takiego obrazu dotąd nie znałam, oraz zbadać, gdzie w tym mieście odnajdę miejsca do spacerów - jedynej aktywności, jakiej można było się oddawać w przestrzeni publicznej. Spacerowałam po ulicach i placach mojego miasta, wybierając te formowane przez budynki o żyjącym wnętrzu i pulsującej zewnętrzności. Unikałam przestrzeni wypełnionych pozbawionymi życia budynkami, którymi na czas pandemicznych ograniczeń opiekowali się jedynie pracownicy ochrony i których elewacje nie miały nic do zaoferowania mnie jako miejskiej wędrowniczce, obserwatorce, uważnie poszukującej relacji pomiędzy budynkami oraz pomiędzy mną a nimi.

Poruszona niemożliwością podróżowania, rozpoczęłam wirtualne wędrówki po Rzymie, korzystając $\mathrm{z}$ internetowych kamer skierowanych w stronę placów i ulic tego miasta. Równolegle zatem, choć przy użyciu innych „narzędzi” i metod, przyglądałam się dwóm miastom - Warszawie i Rzymowi. Nie próbowałam ich porównywać, a jedynie zapisywać spostrzeżenia i opisywać własne doświadczenia oparte na wspomnieniach bycia w realnych przestrzeniach, zapisach video, skrawkach obrazów w formie screenshotów ${ }^{1}$. Zaczęłam z oddali przyglądać się przestrzeni miasta, do którego nie mogłam podróżować. Oglądałam Rzym, korzystając z dostępu do miejskich kamer internetowych, które 24 godziny na dobę transmitują w świat obrazy z ulic i placów miasta. Zobaczyłam miasto, którego nie znałam wcześniej: pozbawione turystycznego gwaru i wyludnione. Życie mieszkańców wycofało się na pewien czas do strefy prywatnej, poza fasady kamienic, do wnętrz ukrytych za grubymi murami. Obserwując przestrzeń Rzymu okiem internetowej kamery, widziałam, jak ulice opustoszałe w wyniku administracyjnych decyzji z czasem, gdy stało się to możliwe, wypełniają się ludźmi, mimo iż pozornie nie mają oni dokąd pójść, a ulubione restauracje i kawiarnie są zamknięte. Obserwowałam ruch mieszkańców w pozbawionym turystów mieście. Miałam wrażenie, że architektoniczny potencjał miasta, jego rozedrgania w płaszczyznach fasad, schody, nisze, podcienie i arkady sprawiają, że przestrzeń miasta jest przyjazna, bo daje się dotknąć, poczuć, pozwala przysiąść i odpocząć, pobyć. 


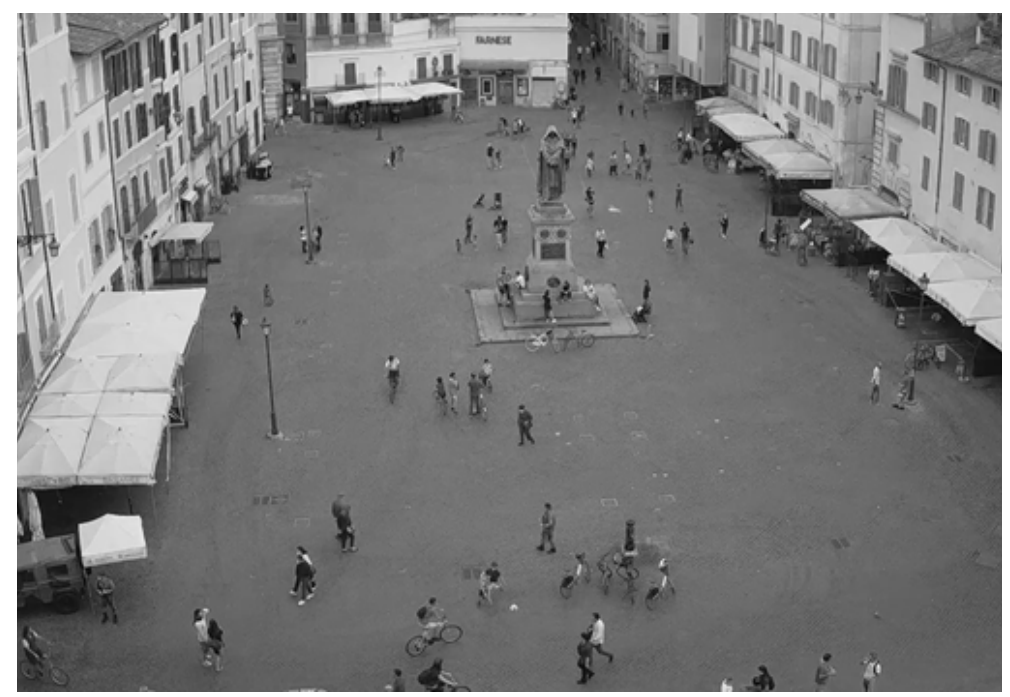

Il. 1. Campo de'Fiori, Rzym, https:/www.skylinewebcams.com/.

Napisałam wtedy krótki tekst, w którym dzieliłam się pierwszymi spostrzeżeniami:

W czasie zarazy życie miasta próbuje toczyć się dalej, zmieniając swój rytm i dostosowując się do trudnych okoliczności i ograniczeń. Wycofuje się do strefy prywatnej, do wnętrz ukrytych za grubymi murami².

Świadomość, że owo życie mimo wszystko „się toczy”, nigdy wcześniej nie nabierała takiego znaczenia. Moje wędrówki, realne oraz te wirtualne, utwierdziły mnie w przekonaniu, że ulica lub plac mogą stawać się miejscem lub nie-miejscem, że mogą być formą wypełnioną poruszającą atmosferą lub jedynie niemą przestrzenią do przebycia. Czas pandemii wciąż wydobywa prawdę o jakości przestrzeni.

\section{Czucie}

Pojęcie przestrzeni w potocznym dyskursie często stosowane jest wymiennie z pojęciem miejsca. Jednakże warto tutaj przypomnieć być może kluczową różnicę między pojęciami przestrzeni i miejsca, która w odniesieniu do rozważania o mieście w czasie pandemii ma duże znaczenie. W architektonicznym kontekście przestrzeń jest obszarem otwartym i abstrakcyjnym, niezdefiniowanym wyraźnie. Miejsce zaś jest częścią owej przestrzeni, konkretną lokalizacją, o szczególnej tożsamości i znaczeniu wynikającym z czynników ją konstruujących. Miejsce można „zobaczyć, poczuć, usłyszeć"3, a zatem jest połączeniem doznań zmysłowych, narracji i pamięci, ujętym w materialne ramy. Miejsce jest również definiowane przez konkretne zdarzenia, dla których jest tłem i które budują jego tożsamość. sach-zarazy/).

3 Bohdan Jałowiecki, Miejsce, przestrzeń, obszar, „Przegląd Socjologiczny”, 2011, t. 60, nr 2-3, s. 23 (źródło: http://cejsh. icm.edu.pl/cejsh/element/bwmeta1.element.desklight-1f86f0a0-c77e-4cec-a249-480c459fd646). 
TOM 2 (2021), NR 1

Przestrzeń jako „miejsce praktykowane” czy też „praktyka miejsc” pojawia się w analizach Michela de Certeau, który rozumie przestrzeń jako miejsce dopełnione ruchem, wypełnione przechodniami miejskie wnętrze. Owa praktyka miejsc staje się zatem zbiorem widoków, zdarzeń, pejzaży, sekwencją doświadczeń, podróżą, w której można uczestniczyć lub w której można być tylko widzem.

\footnotetext{
Podczas gdy - zdaniem de Certeau - przestrzeń powinna być wytwarzana na podstawie i z myślą o doświadczeniu, planowanie przestrzenne czyni ją przedmiotem spekulacji, operacji klasyfikujących i biurokratycznego administrowania ukierunkowanego na eliminację wszelkiej przygodności ${ }^{4}$.
}

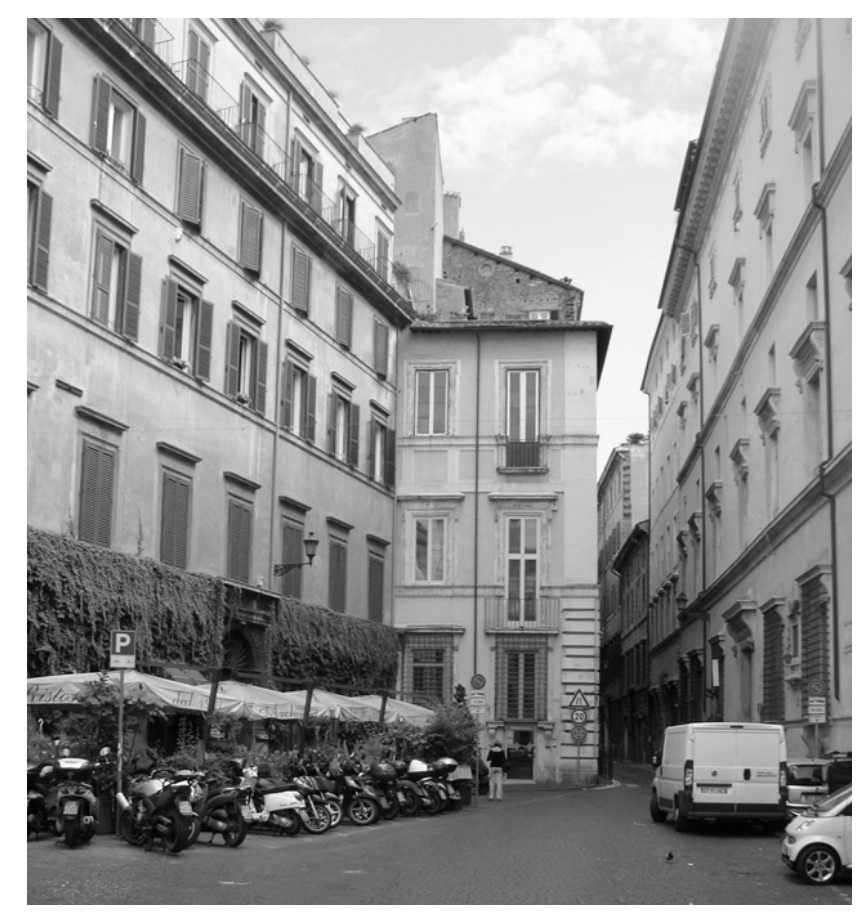

Il. 2. Via Monterone, Rzym, fot. Iwona Kalenik.

Uczestniczenie rozumiane jako bycie w, doświadczanie, wejście w głąb, może być zatem kryterium odróżniającym miejsca od nie-miejsc. Według Marca Augé różnice te dotyczą przede wszystkim kategorii doświadczenia życia społecznego, które w nie-miejscach nie jest możliwe. Miejsca zatem, definiowane przez pryzmat trzech elementów: lokalizacji, znaczeń i aktywności, pozwalają na uczestniczenie w relacjach zarówno na poziomie międzyludzkim, jak i w relacji człowiek-przestrzeń, w przeciwieństwie do nie-miejsc, które mają charakter tranzytowy i na rozwinięcie takowych nie pozwalają. Prawniczy, Ekonomiczny i Socjologiczny", 2008, R. LXX, z. 2, s. 188. 
TOM 2 (2021), NR 1

\section{Bycie w}

Ulica jako podstawowy element przestrzeni miejskiej jest przedmiotem rozważań w różnych kontekstach. Jako składowa architektury miasta w przeszłości stanowiła kameralny „mały świat”, ukształtowany dziejami mieszkańców miasta, wydarzeniami, urozmaicony architektonicznymi wariacjami na ten sam „temat”. I choć nigdy nie stanowiła „,elu” w takim znaczeniu, jakim był plac, to jednak była przestrzenią o wybitnie publicznym charakterze, sprzyjającym spotkaniom, wnętrzem mogącym pomieścić w sobie zarówno intensywność wydarzeń, jak i zachwycający kameralnością spokój.

Współczesne ulice przestały sprzyjać przebywaniu na nich nie tylko poprzez ogromną skalę nowych obiektów tworzących obraz ulicy, ale również przez utratę swojego powierzchniowego charakteru. Norweski architekt Christian Norberg-Schulz, autor książki Bycie, przestrzeń i architektura, zwraca uwagę na niszczący dla przestrzeni ulicy figuralny charakter budynków. Ulica traci swoje ściany, a jej rola zostaje „sprowadzona do podporządkowanego gruntu”. W języku polskim tę podrzędność widać w określaniu adresu. Budynek stoi „na” ulicy. Rzadko „przy”. W przeciwieństwie do języka angielskiego, nie istnieje w ogóle forma „w” ulicy (in the street). Współczesne ulice są więc często ulicami tylko z nazwy, w odniesieniu do administracyjnego adresu, nie stanowią miejsca sprzyjającego przebywaniu, wnętrza o miejskim charakterze, a jedynie powierzchnię wyznaczoną jezdnią, przy której stoją osobne budynki oznaczone numerami. Norberg-Schulz zauważa, że to ulica, a nie budynki, powinna mieć charakter figuralny, żeby stać się prawdziwą formą. Możliwe to jest poprzez istnienie wyraźnej granicy - fasady, stanowiącej ciągłą powierzchnię, o intensywnej gęstości, jak również o swoistym ujednoliceniu, które jednak opiera się na subtelnych wariacjach na temat, a nie monotonii.

Dotyka on niezmiernie ważnej kwestii, jaką jest ciągłość powierzchni fasad budynków. Dotyk będący ich udziałem, rozpatrywany w kategoriach swego rodzaju „emocjonalności miejskiej”, okazuje się kluczowy w wytwarzaniu kameralności, a może nawet intymności ulicy. „,To nie z identycznych, lecz jedynie z podobnych do siebie zbudowana jest lokalna wspólnota fasad, bez której nie byłoby ani ulicy, ani miasta". Bez szczelności pierzei ulica się rozpada, przestaje być wnętrzem, a staje się podłożem z wyznaczoną jezdnią i chodnikiem. Zetknięcia budynków, postrzegane jako granica pomiędzy nimi, „paradoksalnie stają się łącznikami, dzięki którym pierzeja może być łatwiej uchwycona jako jednolita, spójna"7. Wydaje się zatem, że stopień domknięcia wnętrza miejskiego, w tym wypad$\mathrm{ku}$ - ulicy, zależny od szczelności pierzei, ma istotny wpływ na rodzaj miejskiej energii i charakter miejsca. Dla miejskiego spacerowicza znaczenie mają również zetknięcia ścian z nieboskłonem oraz podłożem ulicy - górne i dolne krawędzie pierzei ulicy ${ }^{8}$. Pierwsze ogarniane są jedynie wzrokiem

5 Christian Norberg-Schulz, Bycie, przestrzeń, architektura, Warszawa 2000, s. 83.

$6 \quad$ Monika Zawadzka, Fasada wrzeszczańska. Kamienice pierzejowe, Gdańsk 2017, s. 16.

7 Monika Zawadzka, Miejsca-zetknięcia-fasad jako zagadnienie spójności i dynamiki formy urbanistycznej, praca doktorska, Politechnika Gdańska, 2013 (źródło: Pomorska Biblioteka Cyfrowa: https://pbc.gda.pl/publication/40321). 
TOM 2 (2021), NR 1

i do pewnej wysokości, drugie dostępne są również bardziej namacalnie, w swoim rozrzeźbieniu, ruchliwości linii wyznaczającej styk fasady z posadzką.

Ulicę, tak jak i miejski plac, można rozpatrywać jako figurę, masę powietrza o określonym kształcie, a zatem również wnętrze formowane integralnymi i jednorodnymi pierzejami, które staje się swoistym kontenerem aktywności i wydarzeń tak jak wnętrze budynku. W moich miejskich pandemicznych obserwacjach zadawałam sobie pytanie, czy i jak ta materialna, nieożywiona część miejskiej przestrzeni wpływa na jakość przebywania w miejskich wnętrzach - ulicach i placach. Zauważyłam, że obserwowane przeze mnie przestrzenie o szczelnych, ciągłych i wyraźnie zarysowanych powierzchniach domykających przyciągają nie tylko mnie, ale również innych mieszkańców, mimo iż oferowały tylko swoje nagie mury.

Można zatem powiedzieć, że w kontekście miejskim ulica i plac mogą stawać się przestrzenią, miejscem lub nie-miejscem. I tak ulica lub plac, na których toczy się życie, wypełnione ruchem mieszkańców, są przede wszystkim przestrzeniami, częściami większego systemu miejskiego. Stają się miejscami, gdy przebywanie w ich przestrzeniach wiąże się z doświadczaniem zmysłowym, z czynnościami, przebywaniem, uczestniczeniem. Puste, pozbawione potencjału obecności i uczestniczenia zmieniają się w nie-miejsca, oznakowane systemem informacji, jezdniami ograniczonymi chodnikiem. Plac i ulica „to więc nie tylko ruch, ale nagromadzenie zdarzeń”, wielość czynności osadzonych w konkretnej przestrzeni.

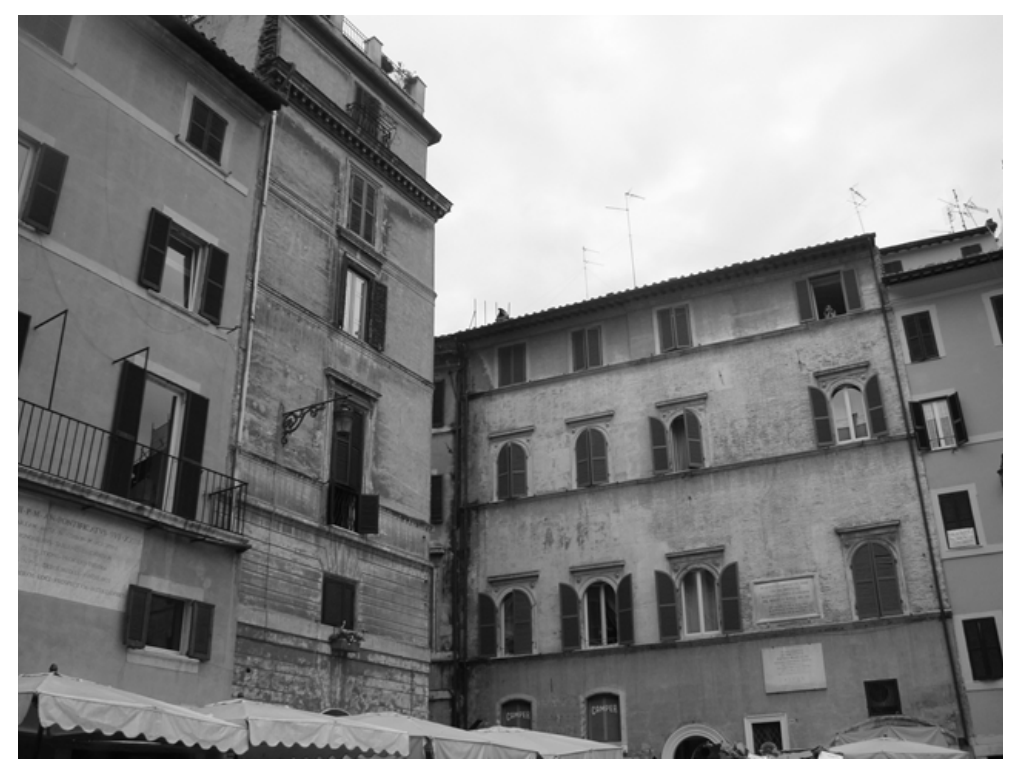

Il. 3. Piazza della Rotonda, fot. Iwona Kalenik. icm.edu.pl/cejsh/element/bwmeta1.element.desklight-1f86f0a0-c77e-4cec-a249-480c459fd646). 
TOM 2 (2021), NR 1

„W skomercjalizowanej przestrzeni miasta jedynie miejsca są w stanie przywrócić równowagę rozczłonowanej, chaotycznej i pozbawionej wartości przestrzeni miejskiej"10 - pisze Małgorzata Dymnicka, analizując problematykę miejsc i nie-miejsc w miejskim kontekście. Przywołuje myśl Yi-Fu Tuana, który przyjął perspektywę rozumienia miejsca jako „uczłowieczonej przestrzeni”, podzielonej na miejsca publiczne i miejsca-pola troski. Te drugie wydają się niejako ważniejsze, lepsze poprzez swój potencjał generowania doświadczeń zarówno międzyludzkich, jak i na poziomie relacji człowiek-miasto. Yi-Fu Tuan wymienia tu dom, ogród, plac targowy, kawiarnię - miejsca, w których wyraźnie spowalnia rytm miejskiego życia, gdzie trzeba się zatrzymać, by w pełni doświadczać ich potencjału.

W kontekście sztuki, jaką jest architektura, bardzo interesującą perspektywą jest ta nawiązująca do formalnych cech przestrzeni jako mających istotny, jeśli nie kluczowy, wpływ na percepcję przestrzeni ulicy jako miejsca. Christian Norberg-Schulz uważa, że ,genius loci jest tworzony przez znaczenia, jakie posiadają budynki, które zbierają (w sobie) cechy miejsca i czynią je bliskie człowiekowi"11. Ta niezwykle ciekawa perspektywa uznaje kluczową rolę budynków w tworzeniu ducha miejsca, atmosfery i aury, która sprzyja lub nie uznaniu ulicy lub placu za miejsce oferujące znacznie więcej niż przestrzeń, jaką zajmuje. Idąc za tym sposobem rozważania zagadnienia genius loci jako tworzonego również przez formę budynków, można postawić tezę, że to właśnie architektoniczne ramy, jako najbardziej namacalne elementy ulicy, mają kluczowy wpływ na uznanie danej przestrzeni za miejsce. To zewnętrzność architektury definiująca kształt przestrzeni publicznej, warstwa pomiędzy wnętrzem budynku a wnętrzem miejskim okazuje się niezwykle ważna. W czasie pandemii obnaża swoją moc zatrzymywania wzroku, zachęcania do dotyku, zbliżenia się, bycia w.

\section{Zatrzymanie}

Wertując książkę Jana Gehla pod tytułem Życie między budynkami, natknęłam się na tytuł rozdziału Przestrzenie do chodzenia, miejsca do zatrzymania się. Poruszył mnie jego sens. Odnajduję w nim, być może niecelowo stworzoną, kolejną kategorię rozróżnienia pomiędzy przestrzenią i miejscem. W rozdziale tym Jan Gehl wymienia różne sposoby bycia w miejskiej przestrzeni: chodzenie, stanie, siedzenie, ale też widzenie, słyszenie i rozmawianie. Pisze on, że „nie wystarczy jedynie stworzyć przestrzenie i pozwolić ludziom na poruszanie się w nich. Muszą zaistnieć również odpowiednie warunki do poruszania się i pozostawania w przestrzeniach [...]"12. Porusza kwestie krajobrazów dla rozmowy, która przecież nie zaistnieje bez spotkania, spowolnienia, zatrzymania się. Szczegółowo

10 Małgorzata Dymnicka, Od miejsca do nie-miejsca, „Acta Universitatis Lodziensis. Folia Sociologica”, 2011, s. 36 (źródło:

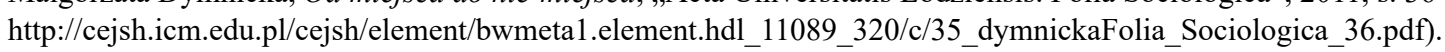

11 Cytat za: Krzysztof Bierwiaczonek, Miejsca i nie-miejsca w perspektywie bàdań nad przestrzeniami publicznymi polskich miast, „Acta Universitatis Lodziensis. Folia Sociologica”, 2018, 64, s. 57; odnośnik w tekście do: Ch. Norberg-Schulz, Genius Loci: Towards a Phenomenology of Architecture, New York1980. Jan Gehl, Życie między budynkami, Kraków 2009, s. 129. 
TOM 2 (2021), NR 1

przygląda się uwarunkowaniom miejskiej przestrzeni, które sprzyjają różnym rodzajom aktywności. To, co zwraca moją szczególną uwagę, to nazywany tak przez Gehla „efekt krawędzi”, związany z narastaniem aktywności od krawędzi danej przestrzeni ku jej środkowi. Przytacza on słowa Christophera Alexandra: „Jeśli zawiedzie krawędź, przestrzeń nigdy nie będzie ożywiona”13. Mnogość form ułatwiających statyczne przebywanie ludzi w strefie krawędzi wydaje się zupełnie niewykorzystana we współczesnych budynkach, które swoją prostotę sprowadzają niekiedy do porażającej mierności, nie oferując nic więcej poza chłodnym lustrzanym odbiciem.

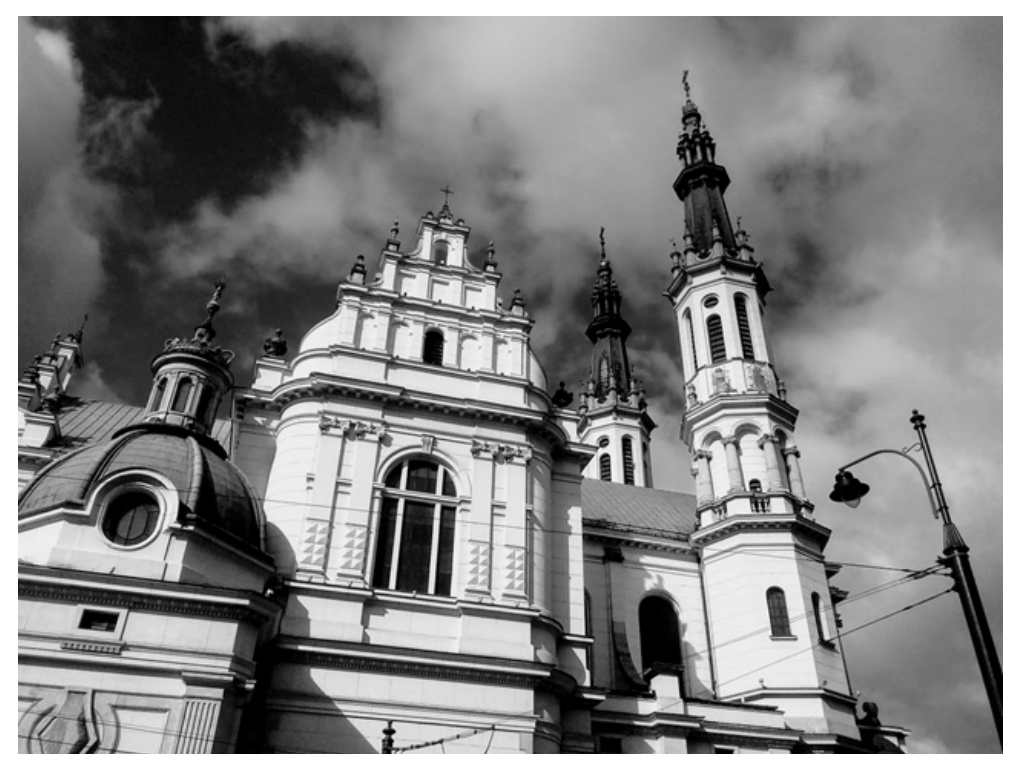

Il. 4. Plac Zbawiciela, fot. Iwona Kalenik.

Kiedy w kolejnym miesiącu pandemii jestem na warszawskim placu Zbawiciela, zachwycam się możliwościami, jakie oferuje w obszarze swoich krawędzi. Rozwarstwienia fasad ujęte w formie podcieni, zagłębień, kolumn, schodków i nisz, ubranych niekiedy w markizy lub zasłony, pozwalają poczuć mi się bezpiecznie jako obserwatorce miejskiego życia. Mogę zatrzymać się w tym miejscu, stać, siedzieć, oprzeć się wygodnie o ściany budynku. Zewnętrzność architektury zaprasza mnie do kontaktu z nią i pozostania w przestrzeni placu. Jego proporcje i różnorodność form budynków zachęcają do obserwacji, nie przytłaczają wielkością, pozwalają ogarnąć wzrokiem krawędź między nimi a nieboskłonem, poczuć ciepło promieni słonecznych, ukryć się w półcieniu, przebywać raczej, niż tylko ,przemierzać”, nawet kiedy nie oferuje żadnej aktywności z okresu tak zwanej normalności.

W pandemicznej rzeczywistości przyglądam się też Piazza di Santa Maria in Trastevere w Rzymie, korzystając z internetowej kamery. To jeden z moich ulubionych rzymskich placów. Spędziłam w nim wiele godzin podczas kilku podróży. To średniej wielkości plac, o wymiarach około $60 \times 40 \mathrm{~m}$, w którego centralnej części znajduje się fontanna. Wschodnią i północną pierzeję placu formują budynki, 
TOM 2 (2021), NR 1

w parterach których ulokowane są kawiarnie i restauracje, z szerokimi parasolami wystawionymi głęboko w przestrzeń placu. W pierzei zachodniej znajduje się arkadowe wejście do bazyliki Najświętszej Maryi Panny na Zatybrzu. To te pierzeje i fontanna odgrywają ogromną rolę w słoneczne dni, kiedy promienie słońca opierają się niejako na nich, pozostawiając $\mathrm{w}$ parasolowym półcieniu pijących kawę mieszkańców Zatybrza. W spokoju poranka mogą przypatrywać się życiu, które toczy się na obrzeżach placu, jak również w jego środkowej części. Widzenie, słyszenie i rozmawianie to aktywności, którym Jan Gehl poświęca kilka stron swojej wspomnianej wyżej książki, uznając możliwość ich wykonywania za kluczową dla uznania przestrzeni za sprzyjającą przebywaniu, ,,przyjemną pod każdym względem"14.

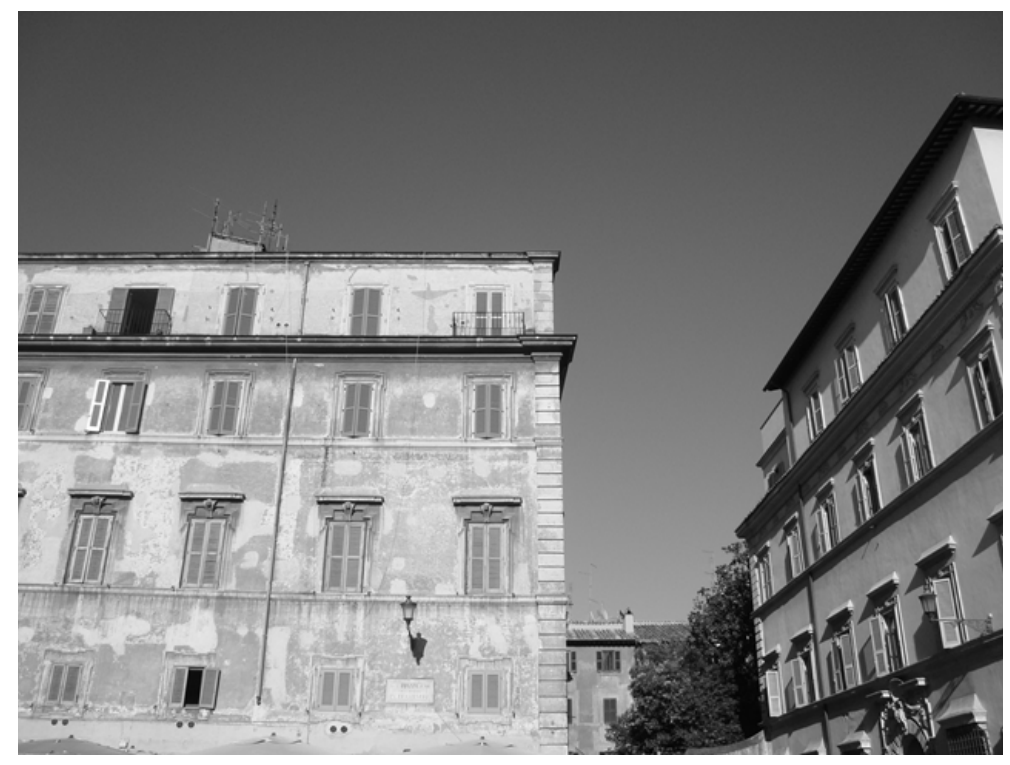

Il. 5. Piazza di S. Maria in Trastevere, fot. Iwona Kalenik.

Przypominam sobie swoje doświadczanie tego miejsca i okiem internetowej kamery przyglądam się uważnie temu, jak Rzymianie korzystają z tego placu w czasie, w którym jedyne, co oferuje, to zewnętrzność architektury. Widzę, że nadal odbywa się swoisty spektakl otwieranych i zamykanych okiennic, który jest sygnałem, że w wewnętrzności architektury toczy się życie. Obserwuję ludzi zatrzymujących się na placu, przysiadających na schodkach fontanny i opierających się na kamiennych słupkach, wokół niej. Nie słyszę, o czym rozmawiają, ale pamiętam, że wnętrze placu sprzyja rozmowom, a usłyszenie drugiego nie wymaga większego wysiłku. Rozmowy przytłumione szumem fontanny mogą być w tym miejscu intymniejsze. Ich natężenie nie rodzi hałasu, gdyż dźwiękowe fale rozbijają się o rozliczne gzymsy, nisze, zgłębienia w ścianach placu. Jakże inne od krótkich komunikatów wykrzykiwanych przez przechodniów na hałaśliwych, wietrznych, ruchliwych drogach. 
TOM 2 (2021), NR 1

Mieszkańcy Rzymu wciąż przebywają w przestrzeni ulic i placów, mimo iż życie społeczne w dużej mierze odbywa się przy użyciu internetowych łączy. I choć nawet rytuał aperitivo znalazł swoją formę online, w której grupy przyjaciół łączą się za pośrednictwem sieci, to dobra przestrzeń miasta wciąż odgrywa znaczącą rolę i przyciąga. Balkony i okna stały się filtrami pomiędzy wnętrzami mieszkań a strefą publiczną, swoistymi scenami manifestów siły przetrwania.

\section{Spotkanie}

„W konkretnej rzeczywistości współczesnego świata miejsca i przestrzenie, miejsca i nie-miejsca mieszają się ze sobą i nawzajem się penetrują. Możliwość nie-miejsca jest zależna od miejsc"15 pisze Marc Augé, przeciwstawiając pojęcia miejsca i nie-miejsca. W ten sposób zestawia ze sobą odmienne, przeciwne rzeczywistości: tranzytu i zamieszkania czy też rzeczywistość „bezkolizyjnego skrzyżowania" i rzeczywistość spotkania oraz doświadczenie pasażera i doświadczenie podróżnika. Jak bardzo pojęcia związane z nie-miejscami wniknęły do języka projektowania, można odczuć w znakomitej większości dyskusji dotyczących problematyki miast. Znamienne, że współczesne miasta wciąż odnajdują sens w języku skrajnej funkcjonalności, czerpiąc wzorce z linii produkcyjnych. „Szybki transport”, „łatwa komunikacja”, „czytelne oznakowanie” stały się symbolami współczesnego, sprawnie działającego miasta, które przypomina w swoim sposobie funkcjonowania lotnisko jeden z przykładów nie-miejsca przytaczany przez Marca Augé. Rzeczywistość pandemiczna obnaża słabość takiego rozumienia zagadnień związanych z przestrzenią miasta. Pandemia zdejmuje z przestrzeni ulicy i placu wszystkie warstwy pozornych atrakcji, wydarzeń, eventów, blichtru, zostawiając jedynie architektoniczne ramy.

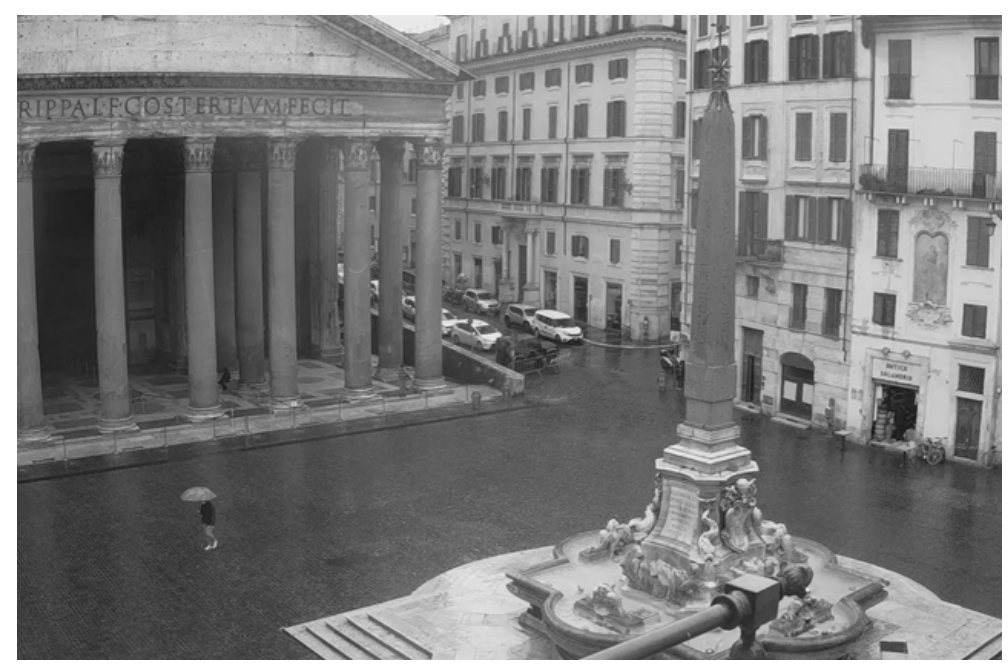

Il. 6. Piazza della Rotonda, https://www.skylinewebcams.com/. 
TOM 2 (2021), NR 1

Patrzę na Piazza della Rotonda - rzymski plac przed Panteonem. Przypominam sobie, że przebywanie w jego wnętrzu było męczące ze względu na liczbę turystów próbujących uchwycić na zdjęciach jedynie siebie i zabytkową budowlę. Gdy oglądam ten plac w czasie pandemii, okiem internetowej kamery widzę, że jest miejscem zupełnie innych aktywności. Porusza mnie, jak bardzo czas pandemii „dał odetchnąć” tej przestrzeni, którą wypełniają teraz jedynie mieszkańcy miasta. Jest teraz naprawdę ich. Właściciel małego sklepiku, znajdującego się we wschodniej pierzei placu, wychodzi, by pograć w piłkę z przypadkowymi osobami przebywającymi na placu. Posadzka placu na dłuższą chwilę staje się swoistą areną, miejscem nieskrępowanej zabawy wypełnionej okrzykami radości. Na schodach fontanny znajdującej się w środkowej części placu przysiadają miejscy spacerowicze, którzy na moment stają się widzami. Przyglądają się grze, ale też spoglądają na rozrzeźbienia fasad kamienic, detale. Wzrok przyciąga znajdujące się nad wejściem do sklepiku fasadowe malowidło przedstawiające Madonnę. Znów widzę nieregularny rytm uchylania i domykania okiennic. Wyżej, bliżej nieboskłonu, zobaczyć można dynamiczną krawędź gzymsów i nakładające się na siebie obrazy bliższych i dalszych pierzei aż dziewięciu ulic otwierających się na plac. To właśnie jednorodność fasad, delikatne ugięcia pierzei, zdeformowania o niewielkich kątach pozwalają czuć się we wnętrzu, w zamkniętej, kameralnej przestrzeni placu. Mam wrażenie, że obserwuję prawdziwe życie tego miejsca, wnikam w tę swobodną atmosferę, niemal uczestniczę w tym jakże realnym i spontanicznym spektaklu miejskich aktywności.

Wędruję po moim mieście. Chcę być miejską podróżniczką, flaneuse ${ }^{16}$. Szukam miejsc, w których w czasie pandemii mogę przebywać, mimo iż pozornie nic się w nich nie dzieje. Poszukuję zatem kameralnych miejskich wnętrz, o które trudno w Warszawie. Śródmiejski, gęsty przedwojenny system ulic i placów nie istnieje, a współczesna przestrzeń wciąż pozostaje zdegradowana, rozbita planistycznymi decyzjami. Gdzieniegdzie jednak odnajduję ulice, które mnie przyciągają. Tak jak ulica Kozia niewielka uliczka łącząca Miodową i Trębacką. Od strony szerokiej w tym miejscu ulicy Nowy Świat trudno dostrzec jej początek, ponieważ jest jakby „rozwarstwieniem” tego układu, a swoją szerokością jedynie subtelnie daje znać o swojej obecności. Już wewnątrz ulicy można poczuć niezwykłą bliskość budynków, ten fizyczny mierzalny niewielki dystans, ale również jednorodność, spójność i szczelność obu pierzei. Są rozrzeźbione, bogate w detale, zagłębienia, uskoki i nierówności. Patrząc na plan ulicy, łatwo zauważyć, że mniej więcej połowie jej długości brakuje zachodniej pierzei. Jednak to tylko percepcyjna pomyłka. W rzeczywistości na tym odcinku zamiast fasad budynków znajduje się „fasada” muru z łukowatymi „oknami”, przez które dostrzec można zadrzewione ogromne podwórze. Lekko falujący kształt wnętrza ulicy nie pozwala dostrzec jednocześnie obu jej końców. Mój spacer to doświadczenie nieustannego nakładania się widoków, obrazów tego miejsca, ciągłej wizualnej gry pomiędzy pierwszym a drugim planem, obserwacji delikatnych deformacji kształtu

16 Flâneuse - franc., żeńska forma słowa flâneur - miejski włóczęga, spacerowicz, postać flâneura zaistniała w twórczości Charles'a Baudelaire'a i od tego czasu termin ten obecny jest w dyskursie dotyczącym zjawisk kultury. 
TOM 2 (2021), NR 1

ulicy świadczących o jej indywidualnym charakterze. Obie pierzeje łączy w połowie ich długości niewielki budynek nazywany ,warszawskim mostem westchnień”. Idąc ulicą w czasie pandemii, napawam się jej spokojem i ciszą, ale też widzę dwoje ludzi, którzy przysiedli na niskim parapecie okna jednej z kamienic. W okiennej niszy rozmawiają i wystawiają twarze do wiosennego słońca.

\section{Dialog}

Peter Zumthor przytacza bardzo szczegółową notatkę ${ }^{17} \mathrm{z}$ przebywania w przestrzeni jednego z europejskich placów, jaką wpisał do swojego notesu w Wielki Czwartek 2003 roku. W lapidarnych zdaniach precyzyjnie opisuje swoje obserwacje i wrażenia. Pisze o zatopionych w słońcu ścianach kamienic i fasadzie kościoła, o przyjemnym niebieskawym cieniu po drugiej stronie placu, o mieszance odgłosów rozmów, delikatnego stukania butów o bruk i głosów ptaków. Pisze o tym, co go porusza w tym miejscu, wymieniając po kolei: ludzie, powietrze, dźwięki kolory, materiały, tekstury, formy. Szczegółowo przygląda się każdemu detalowi tego miejskiego wnętrza. Ale pisze również o swoich odczuciach, nastroju. I dzieli się spostrzeżeniem, że „nie mógłby odczuwać tego wszystkiego, gdyby nie atmosfera tego placu"18. A zatem odnosi się do cech sensorycznych miejsca, w którym przebywa, a które rozpoznaje poprzez własną wrażliwość. Mam nieodparte wrażenie, że Peter Zumthor, pisząc tę notatkę, siedział przy restauracyjnym stoliku wystawionym na jeden z rzymskich placów.

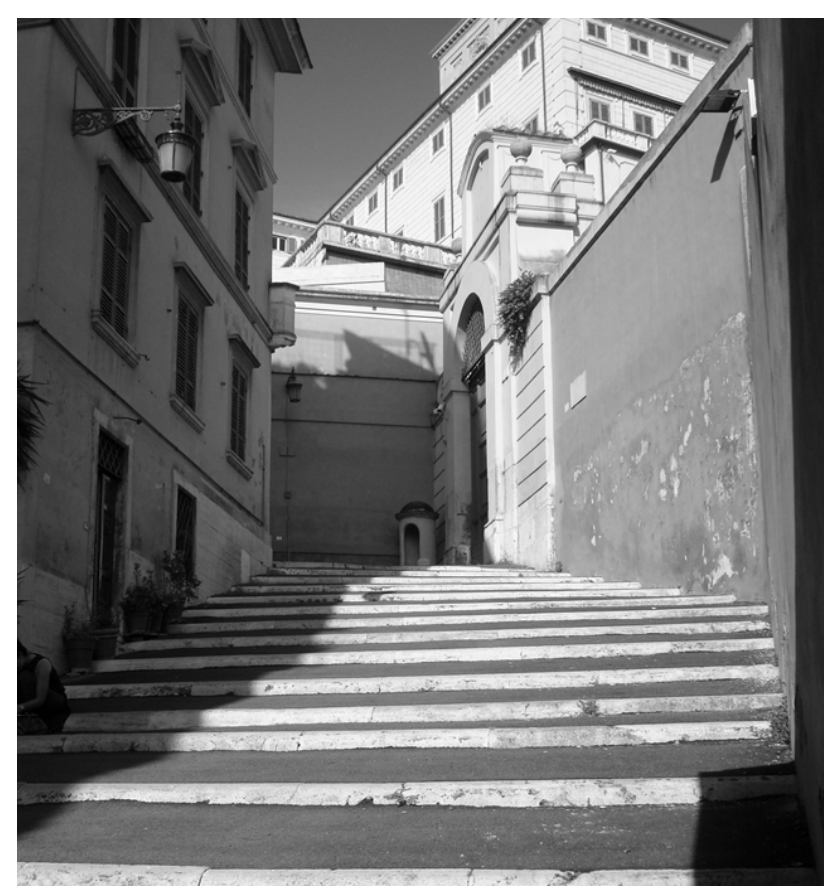

Il. 7. Rzym, fot. Iwona Kalenik 
TOM 2 (2021), NR 1

W mojej pracy doktorskiej posługiwałam się pojęciem przestrzeni pustki w odniesieniu do miejskich wnętrz. „Nie można projektować pustki, ale można projektować jej granice”19 - pisze Peter Zumthor, którego myśl projektowa jest mi bardzo bliska, zwłaszcza w kontekście miejskiej przestrzeni. Zwraca on uwagę na niezwykle istotną rolę powierzchni formujących wnętrza miejskie - fasad budynków, krawędzi i posadzek, które decydują o jej cechach odczuwalnych zmysłowo i o osobistym doświadczaniu przestrzeni. Rozpatrywanie przestrzeni ulic i placów jako pustki o określonym kształcie, które można odczytywać przy pomocy zmysłów, mające swoje zapachy, dźwięki, kolory i światło, rozszerza rozumienie miasta o dodatkową warstwę opartą na pozafunkcjonalnych aspektach. Przestrzeń publiczna, jaką jest ulica albo plac, staje się prawdziwie wnętrzem miejskim, kiedy stwarza możliwość spotkania i przebywania w nim, niezależnie od przeznaczenia budynków, jakie je formują. Staje się miejscem, gdy posiada swoją, trudno mierzalną, ale wyraźnie wyczuwalną atmosferę sprzyjającą spowolnieniu, zauważaniu detali, spotkaniu. Atmosfera jest abstrakcyjnym pojęciem, które - podobnie jak piękno - jest niechętnie podejmowane w dyskursie dotyczącym kształtowania przestrzeni miast. Powstaje jednak w wyniku interakcji pomiędzy materią miasta, architekturą i człowiekiem. Jest zatem związana z obecnością, przebywaniem, „,byciem w”. „Masa budowli nie przemawia jednak tylko obrazem. Jej siła polega na możliwości rzeczywistego jednoczesnego doświadczania jej samej oraz przestrzeni pustki, którą formuje" ${ }^{20}$. Kluczowa w budowaniu siły miejskiej pustki wydaje się zatem zewnętrzność architektury formującej miejskie wnętrza. Płynne, trudne do określenia zetknięcie między zewnętrzem budynku a wnętrzem placu lub ulicy zawiera w sobie potencjał atrakcyjności publicznej przestrzeni miasta. To na tym pograniczu, w przestrzeni fasady budynku rozgrywa się architektoniczny dialog, o którym pisze profesor Jacek Dominiczak:

Oto gdy wewnętrzna ściana fasady jest granicą „,wewnętrzności” budynku i projektowana jest z-wewnątrz-na-zewnątrz, zewnętrzna ściana fasady jest granicą jego ,zewnętrzności” i projektowana jest z-zewnątrz-do-wewnątrz. Przestrzeń pomiędzy warstwami fasady to fenomen dialogiczności - w niej fizycznie realizuje się etyczny wymiar architektonicznego spotkania. Nie tylko dlatego, że coś się w nim wydarza, ale że jego forma stwarza możliwość przebywania bez jasno sprecyzowanego celu. Przebywanie samo w sobie w takim wnętrzu jest satysfakcjonującym procesem ${ }^{21}$.

19 Peter Zumthor w wywiadzie przeprowadzonym przez Barbarę Stec, Trzy rozmowy z Peterem Zumthorem, „Architektura \& Biznes", 2003, nr 2 .

20 Iwona Cała (Kalenik), W objęciach miasta. Architektura jako emanacja bliskości, praca doktorska, Akademia Sztuk Pięknych w Gdańsku, 2018, s. 54.

21 Jacek Dominiczak, Miasto dialogiczne i inne teksty rozproszone, Gdańsk 2016, s. 80. 


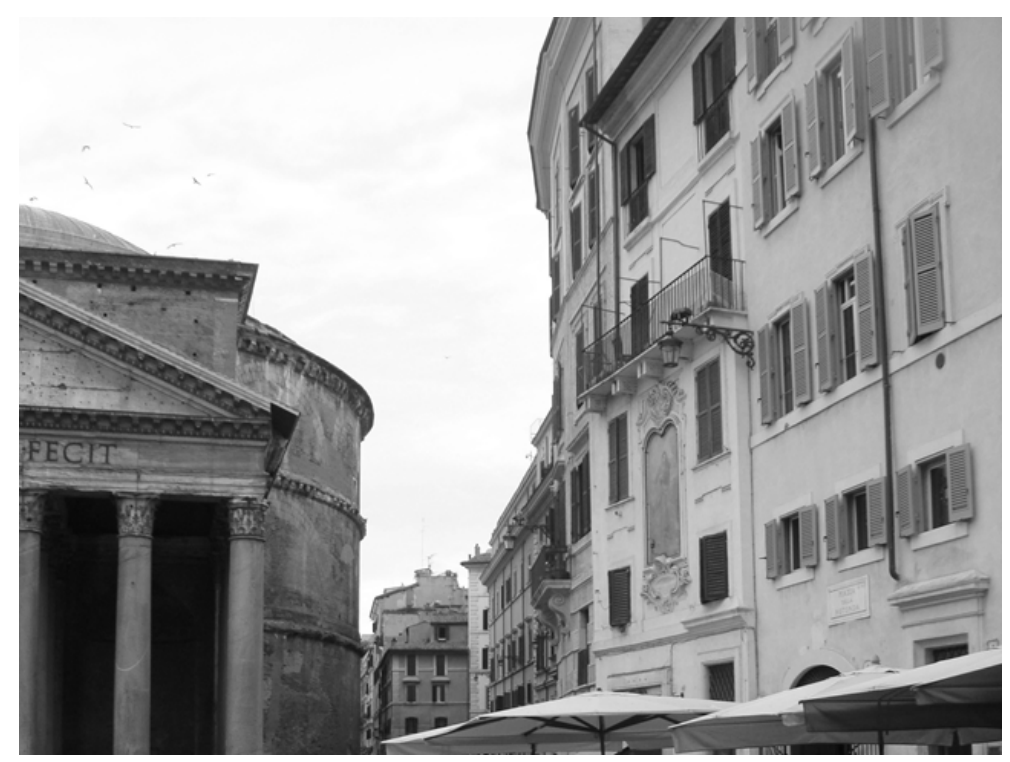

Il. 8. Piazza della Rotonda, fot. Iwona Kalenik.

Moje obserwacje ulic i placów Warszawy i Rzymu utwierdziły mnie w przekonaniu, że miejskie ulice i place mogą wzmacniać realne, haptyczne doświadczanie architektury miasta. Idąc za myślą Gordona Cullena ${ }^{22}$, jestem niemalże pewna, że klimat miejsca, jego jakość architektoniczna i potencjał uczestniczenia odpowiadają za budowanie charakteru przestrzeni, a w konsekwencji za zatrzymanie i przebywanie w niej. Nie bez przyczyny wnętrza ulic i placów starych miast przyciągają tak bardzo. Ich fenomen tkwi nie tyle w dziejowej historii miejsc, ile w swoistej mieszance atmosfery, geometrycznych proporcji i ekspresji wizualnej.

Miasto w pandemii, ale też i w tak zwanym normalnym czasie, może stać się nie-miejscem, które raczej się przemierza, niż w którym się w nim przebywa, i w którym czas jakby nie istnieje. Jego przestrzeń może przypominać rodzaj portalu służącego jedynie do przemieszczania się od-do, z jednego miejsca do drugiego. Szerokie ulice, pozbawione gwaru rozmów, wypełnione hałasem ruchu kołowego stają się trasami, tranzytowymi arteriami. Jednak miasto pandemiczne wciąż przecież łączy w sobie wątki historyczne, tożsamościowe, znajome, oswojone wcześniej. To wciąż ulice i place, będące przestrzeniami wspólnot, miejscami spotkań, noszącymi w sobie ślady ludzkich radości i dramatów, zdarzeń, zakorzenione w dziejach miasta i pamięci zbiorowej mieszkańców. To wciąż ramy ludzkiej egzystencji, w której musi toczyć się życie niezależnie od okoliczności. 
TOM 2 (2021), NR 1

\section{Bibliografia}

Dodatkowy wewnętrzny nawias [] we wpisie bibliograficznym zawiera rok pierwszego wydania, co pozwala lepiej zorientować się w okresie, z jakiego dany tekst pochodzi.

Alexander Christopher, Język wzorców. Miasta, budynki, konstrukcja, Gdańsk 2008 [1977].

Bierwiaczonek Krzysztof, Miejsca i nie-miejsca w perspektywie badań nad przestrzeniami publicznymi polskich miast, „Acta Universitatis Lodziensis. Folia Sociologica”, 2018, 64.

Botton Alain de, Architektura szczęścia, Warszawa 2010 [2008].

Cała (Kalenik) Iwona, $W$ objęciach miasta. Architektura jako emanacja bliskości, praca doktorska, Akademia Sztuk Pięknych w Gdańsku, Gdańsk 2018.

Gehl Jan, Życie między budynkami. Użytkowanie przestrzeni publicznych, Kraków 2013 [1971].

Hall Edward Twitchell, Ukryty wymiar, Warszawa 2003 [1982].

Jałowiecki Bohdan, Miejsce, przestrzeń, obszar, „Przegląd Socjologiczny”, 2011, t. 60, nr 2-3, s. 9-28.

Lynch David, Obraz miasta, Kraków 2011 [1960].

Norberg-Schulz Christian, Bycie, przestrzeń, architektura, Warszawa 2000 [1971].

Pallasmaa Juhani, Oczy skóry. Architektura i zmysty, Kraków 2012 [2005].

Pallasmaa Juhani, Myślacca dtoń, Kraków 2015 [2009].

Stec Barbara, Trzy rozmowy z Peterem Zumthorem, „Architektura \& Biznes”, 2003, nr 2.

Tamborrino Rosa, Coronavirus: locked-down Italy's changing urban space, The Conversation, 2020, https:// theconversation.com/coronavirus-locked-down-italys-changing-urban-space-133827.

Tuan Yi-Fu, Przestrzeń i miejsce, Warszawa 1987 [1977].

Zawadzka Monika, Fasada wrzeszczańska. Kamienice pierzejowe, Gdańsk 2017.

Zawadzka Monika, Miejsca-zetknięcia-fasad jako zagadnienie spójności i dynamiki formy urbanistycznej, praca doktorska, Politechnika Gdańska, Gdańsk 2013.

Zumthor Peter, Myślenie architektura, Kraków 2010 [1998].

Zumthor Peter, Atmospheres, Bazylea 2009 [2006]. 
TOM 2 (2021), NR 1

\section{Źródla fotografii}

https:/www.skylinewebcams.com/pl/webcam/italia/lazio/roma/campo-de-fiori.html https://www.skylinewebcams.com/pl/webcam/italia/lazio/roma/pantheon.html 
TOM 2 (2021), NR 1

Utwór udostępniany na licencji Creative Commons Uznanie autorstwa 4.0 Międzynarodowe

Artykuł recenzowany

Wydawca: Akademia Sztuk Pięknych im. Jana Matejki w Krakowie, Wydzial Architektury Wnętrz

Redakcja: prof. dr hab. Beata Gibala-Kapecka, dr Joanna Lapińska

Opracowanie graficzne: Joanna Łapińska

Fotografia na stronie tytułowej: Iwona Kalenik

Czasopismo „inAW Journal - Multidisciplinary Academic Magazine” powstało dzięki dofinansowaniu w ramach projektu „Projektowanie przyszłości - program rozwoju Akademii im. Jana Matejki w Krakowie na lata 2008-2022” 